\title{
Depositional Evolution and Sedimentary Architecture related to drowning of the Sepetiba Bay (RJ) during the last deglaciation
}

Guilherme Amendola dos Santos, Antonio Tadeu dos Reis

Copyright 2019, SBGf - Sociedade Brasileira de Geofísica

This paper was prepared for presentation during the $16^{\text {th }}$ International Congress of the Brazilian Geophysical Society held in Rio de Janeiro, Brazil, 19-22 August 2019.

Contents of this paper were reviewed by the Technical Committee of the $16^{\text {th }}$ International Congress of the Brazilian Geophysical Society and do not necessarily represent any position of the SBGf, its officers or members. Electronic reproduction or storage of any part of this paper for commercial purposes without the written consent of the Brazilian Geophysical Society is prohibited.

\section{Abstract}

The Seismic data we acquired in the Sepetiba bay (Rio de Janeiro - Brasil), show a different aspects of the stratigraphic sucesson in the previous studies. We found a complex paleo-fluvial system, result of the last glacial maximum in the area. The stratigraphic succession show a evolution of the paleoenvironments, starting with a complex fluvial system, that overpass the current barrier island, Restinga da Marambaia, to a fluvial-estuarine system and the total closure of the Sepetiba Bay

\section{Introduction}

The Sepetiba Bay, located on the west coast Rio de Janeiro State (Fig 1.), consists of an embayment where estuarine conditions prevail, due to limited contact with the open ocean because of the existence of Restinga da Marambaia - an extensive barrier island of some $40 \mathrm{~km}$ extent.

The few previous studies available in the scientific literature of the area propose variable geomorphological and oceanographic evolution scenarios for both the bay and the barrier island during the late PleistoceneHolocene (latest $130 \mathrm{ky}$ ) (PONÇANO et al. 1979; BORGES, 1998); . Although such studies have proposed different ages and sediment dynamics associated to the barrier island closure, they all assume that the sandy barrier island occupies a structural high that would have permanently prevented the direct connection of the inland drainage basin with the adjacent continental shelf during periods of glacial maxima (BORGES, 1998).

However, recent studies carried out by our research group GEOMARGEM (FRIEDERICHS, 2012; FRIEDERICHS et al, 2013; MATOSO, 2014) in the adjacent continental shelf revealed the occurrence of a rather developed paleo-fluvial system of presumable Upper Pleistocene-Holocene age on the inner-mid shelf, extending up to $\sim 30 \mathrm{~km}$ away from the coast, until some $60 \mathrm{~m}$ depth - corresponding the external limit of the available data base. Such fluvial system lays in direct connection with the upstream catchment basin of
Sepetiba region, crossing the area of the present-day Marambaia barrier island depositional system.

In such a context, the present study, still under way, is based on the seismic analysis of circa $200 \mathrm{~km}$ of highresolution reflection seismic data (boomer 100-300 J), recently acquired during Sepetiba I and II survey cruises (Fig 1). The study aims at identifying paleo-fluvial systems in the stratigraphic succession of the Sepetiba bay area, as well as at establishing their connection to the paleofluvial system already identified on the adjacent continental shelf.

Data analysis reveals the existence of fluvial incisions correlated to the downstream system preserved on the shelf. Ongoing analysis reveals thus that the crystalline basement was not high enough to prevent the upslope fluvial system to drain directly into the adjacent continental shelf during periods of sea-level lowering, what points to a rather distinct paleogeographic configuration of the bay during the late PleistoceneHolocene than previously proposed.

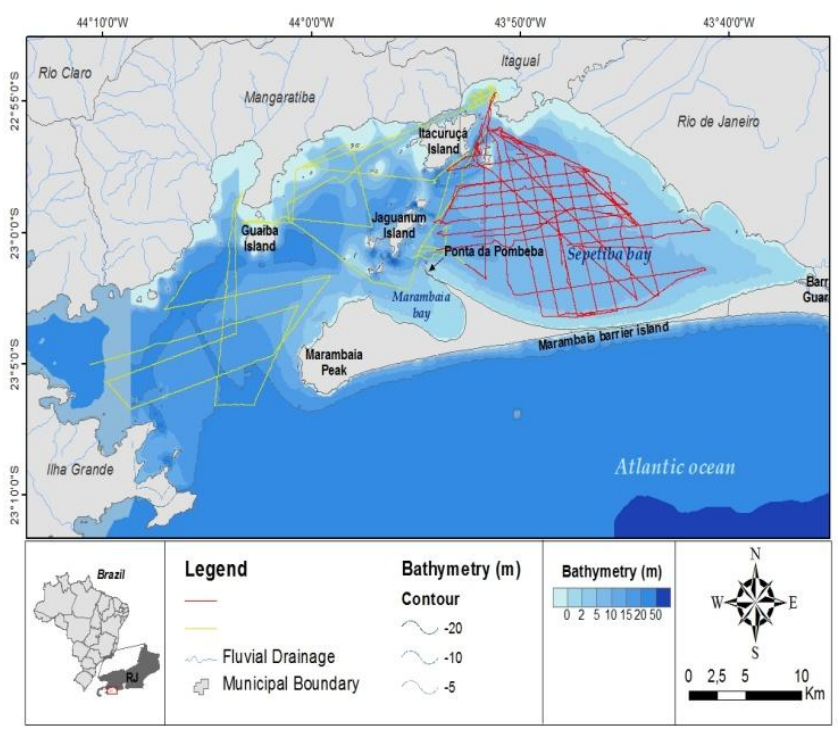

Figure 1 - Study area with the seismic data acquired during Sepetiba I and II survey cruises 


\section{Method}

The seismic stratigraphic analysis in this study integrates 2D high-resolution seismic line data interpretations, acquired high-resolution single channel boomer AA301 ( Frequency between $1-5 \mathrm{kHz}$ and potency $200-300 \mathrm{~J})$. This seismic data was acquired in the two different cruises, Sepetiba I and II, occurred between September 2012 and January 2013. The Boomer AA301 circa 50 ms penetration into the sub floor and we considered a layer velocity of $1600 \mathrm{~m} / \mathrm{s}$ to estimate the thickness of each seismic sequence

\section{Results}

The interpretation of the seismic data show four different unities that represents the environmental evolution of the area. The four units, U1, U2, U3 and U4 were limited by four different surfaces that represents the stages of evolution of the Sepetiba Bay (Fig. 2.)

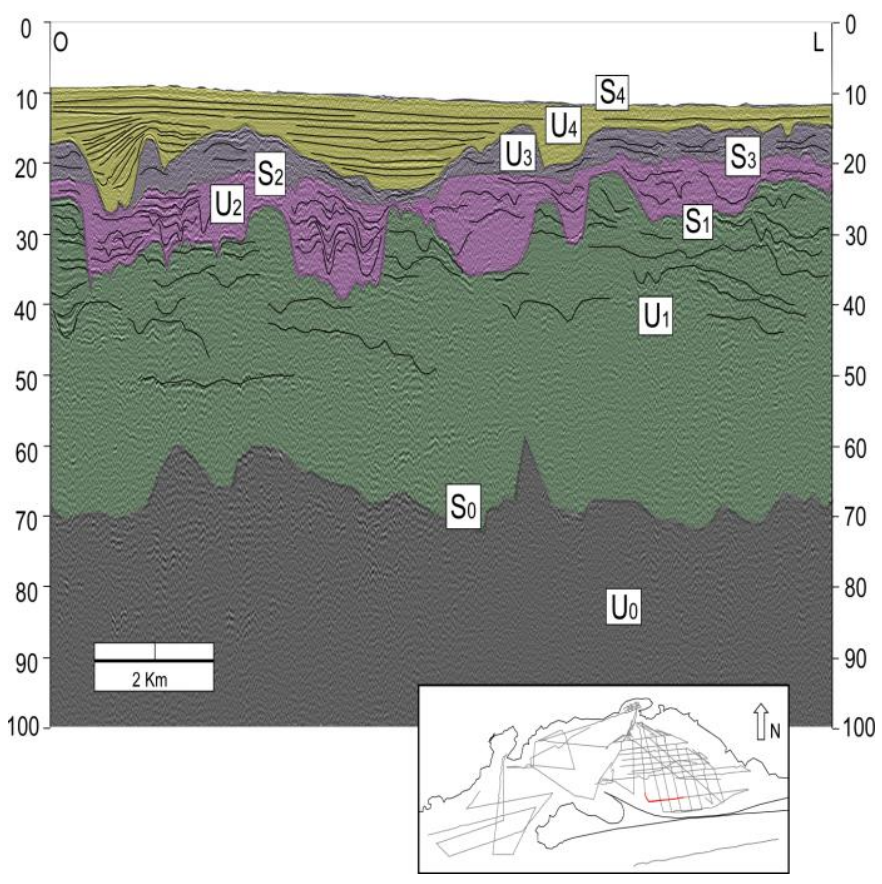

Figure 2 - Units and surfaces identified in the study area

The U1 seismic unit is the first sedimentary package found in the study area and its base is bounded by acoustic basement. The surface that limits the top of this unit (surface S1) is very irregular, showing its erosive character, often presenting well-defined canalized incisions, with different widths varying between 300 and 1300 meters, and depths ranging from 4.5 and 7 meters, compatible with the interpretation of fluvial paleocannals (Fig. 3). The main characteristic of the internal reflectors of the U1 unit is the presence of sub-parallel reflectors, often discontinuous, and ending in erosive truncations with the channeled incisions of the surface S1.

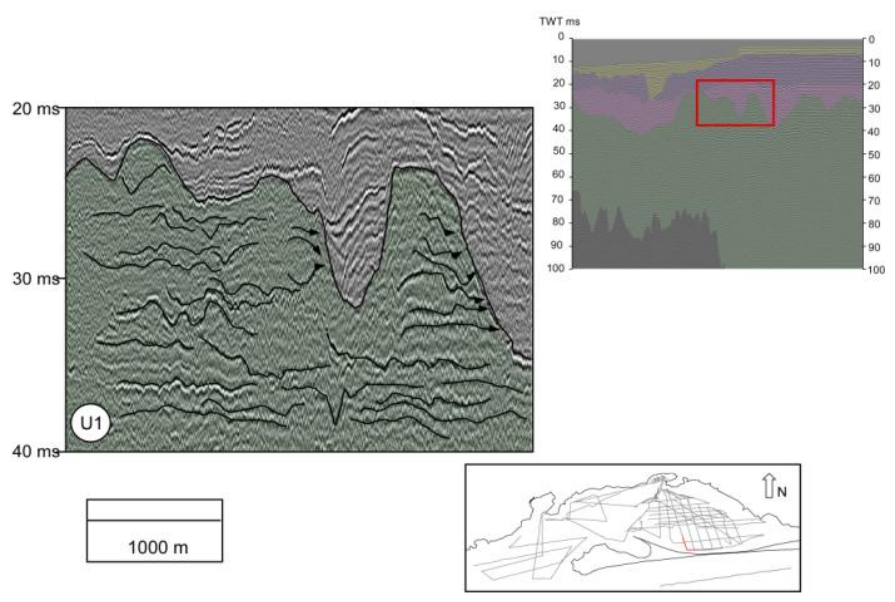

Figure 3 - Detailing of seismic unit U1

The seismic unit $\mathrm{U} 2$ is bounded at the base by the surface S1 and at the top by the surface S2 (Fig. 2). Its top is characterized by being a more regular and continuous surface, sometimes presenting some small channels. The seismic unit is marked by the superposition of channeled cut-and-fill features with continuous undulating reflectors and features of lateral channel migration without clearly defined hierarchy (Fig.4). The size of the channels and the successive features of cut and fill without a clear hierarchy suggests that it is a highenergy estuarine fluvial environment that would register a progressive change in the base level of the region.
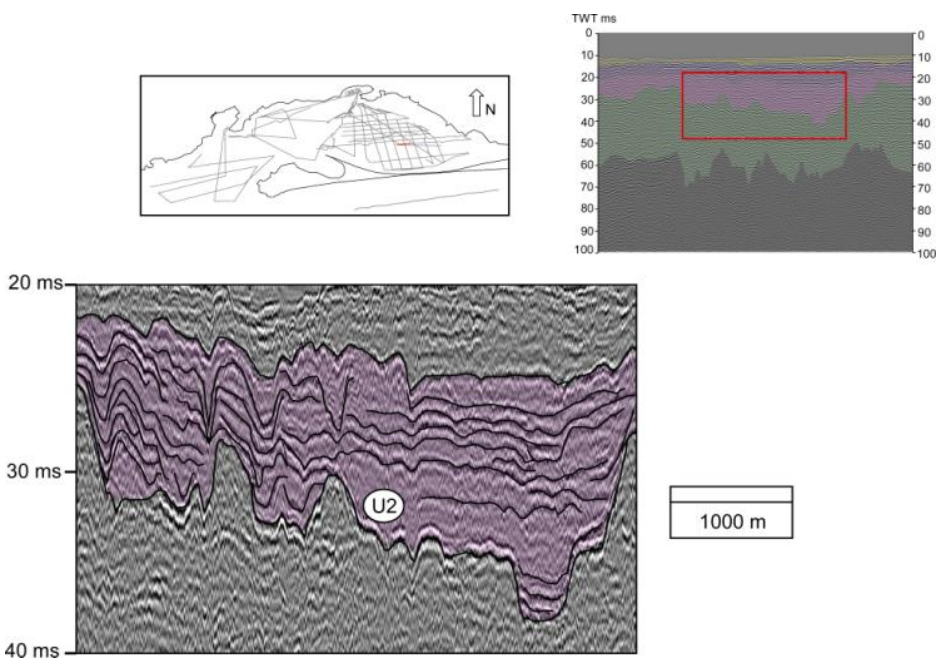

Figure 4 - Detailing of seismic unit U2 
The seismic unit U3 has its base bounded by the surface S2 and its top bounded by the surface S3 (Fig. 2). Like unit U2, unit U3 is also represented by multiple channels. However, the U3 unit presents a predominance of discontinuous corrugated reflectors interspersed with more transparent facies (Fig. 2). The internal configuration of the unit, with the presence of smaller and more sparse channels than those of unit U2, is interpreted as the record of changes in the dynamics of Sepetiba Bay, passing into a gradual environment of lower energy to an open low energy estuary.
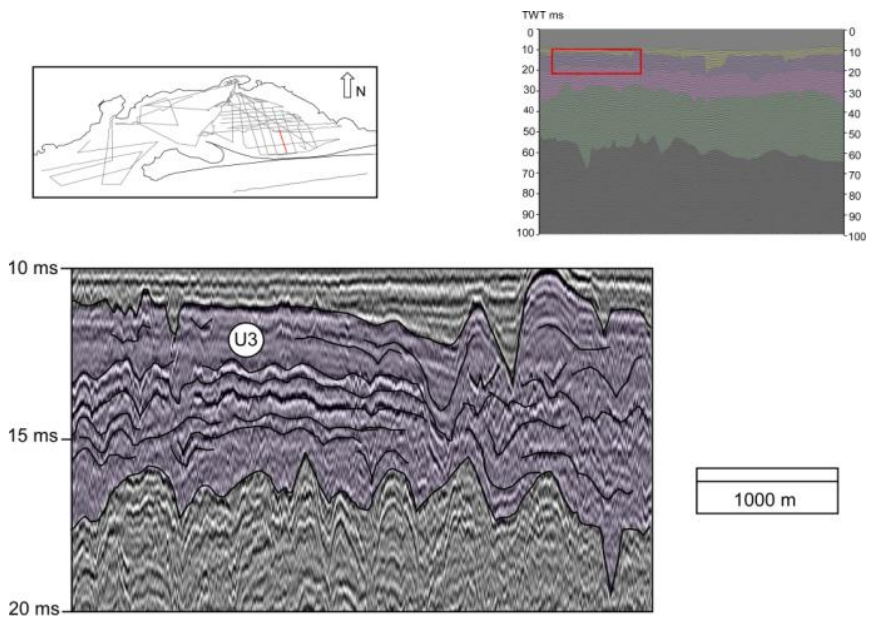

Figure 5 - Detailing of seismic unit U3

The seismic unit $\mathrm{U} 4$ is the last unit observed in the region and is bounded at its top by the current bay ocean floor (surface S4) and at its base by surface S3 (Fig. 2). Its internal configuration is characterized by continuous plane-parallel reflectors, and absence of internal channels. Channels are seen only in isolation at the base of the unit. The internal reflectors configuration of the U4 unit reflects a fairly low energy environment, interpreted as the insulation record of the open sea bay region - into an enclosed estuary. The base of this unit presents some channels with flat-parallel filling, recording the change in the region's circulation.
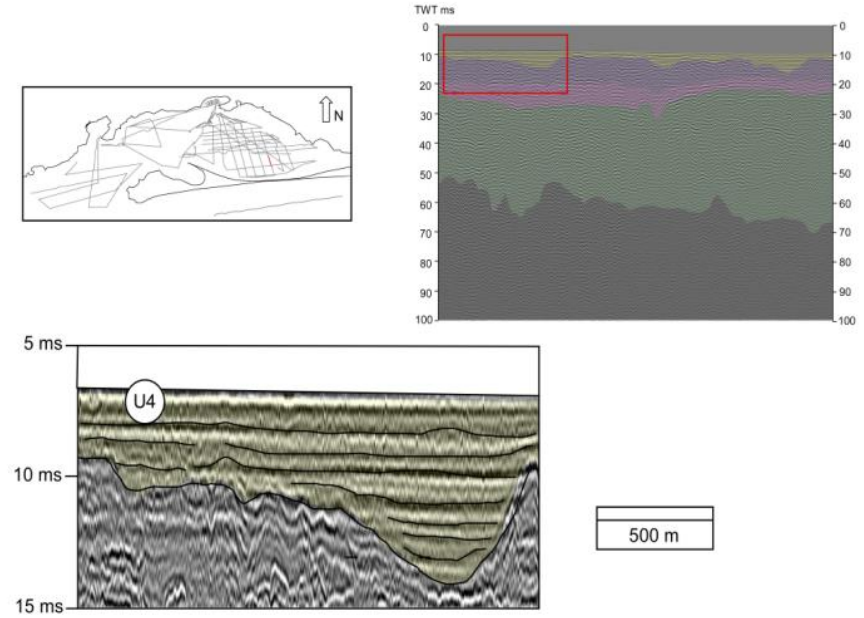

Figure 6 - Detailing of seismic unit U4

The interpretation also allowed us to identify different generations of paleocannals, interpreted as the record of different moments of the environmental evolution of the Bay of Sepetiba. The first generation was interpreted on the surface $\mathrm{S} 1$ and is represented by a series of channeled incisions, often having a clear hierarchy, and interpreted as fluvial paleocannals. In terms of dimensions, these incisions have widths varying between 300 and 1300 meters and depths varying between 4.5 and 7 meters. The filling of these channels shows a transition from a fluvial-estuarine system to a high-energy estuarine system (Fig. 7. Through the correlation between the seismic lines it was possible to identify and trace the main channels within the Sepetiba Bay and the adjacent shallow platform near Restinga da Marambaia.

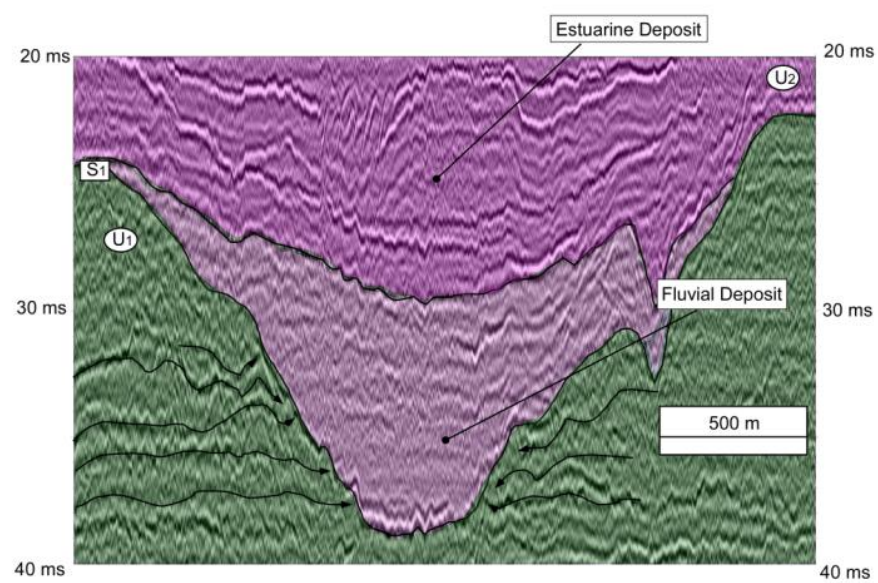

Figure 7 - Paleochannel identified in the study area in the surface $\mathrm{S} 1$. The filling shows the transition of a fluvial system to a high energy estuarine System 
In the region of the shallow platform, identified 3 paleocannals correlated with the identified channels within the bay (Fig. 7). From the reconstruction of the paleo-river system we verified that the old fluvial drainage surpassed the region of the present barrier island, evidencing that the basement did not prevent the progression of the paleo-river system to the shallow platform. The identification of the main channels also allowed the correlation with the current drainage network of Sepetiba Bay (Fig. 9)

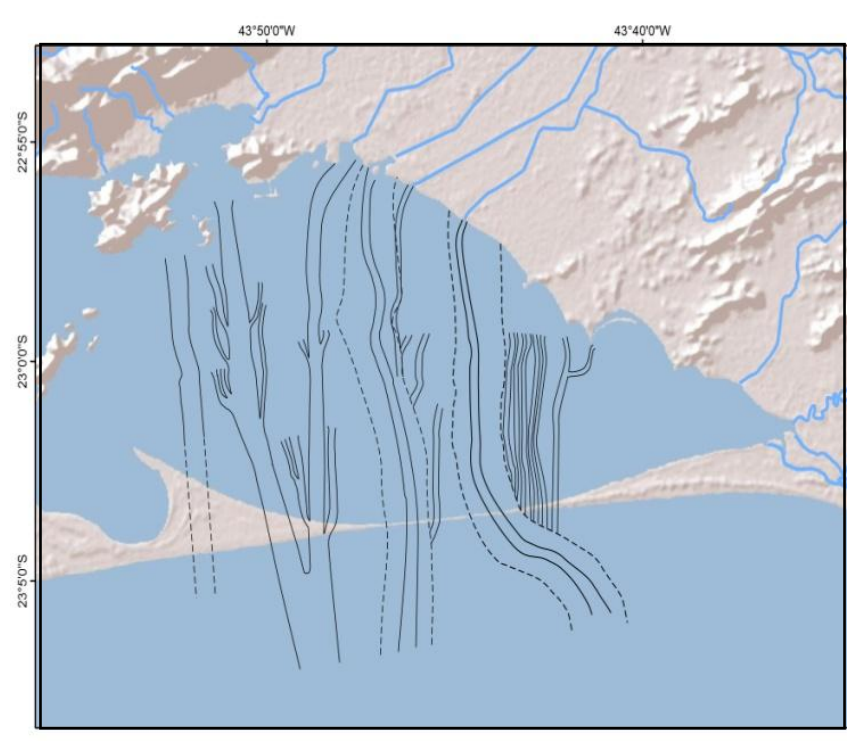

Figure 9 - Paleo - River system of Sepetiba bay excavated in the surface S1, made from the interpretation of the seismic data

We also found a great paleochannel excavated in the surface S3. This feature is represented by a single, extensive paleocanal parallel to the present barrier island, Restinga da Marambaia, with an extension of $19 \mathrm{~km}$ and a maximum width of 700 meters. Its filling is characterized by continuous plane-parallel reflectors, showing a deposition in low energy environment (Fig 10). Due to its filling, this paleocanal records the change of circulation in the region caused by the confinement of the region, being correlated to the closure of the present barrier island.

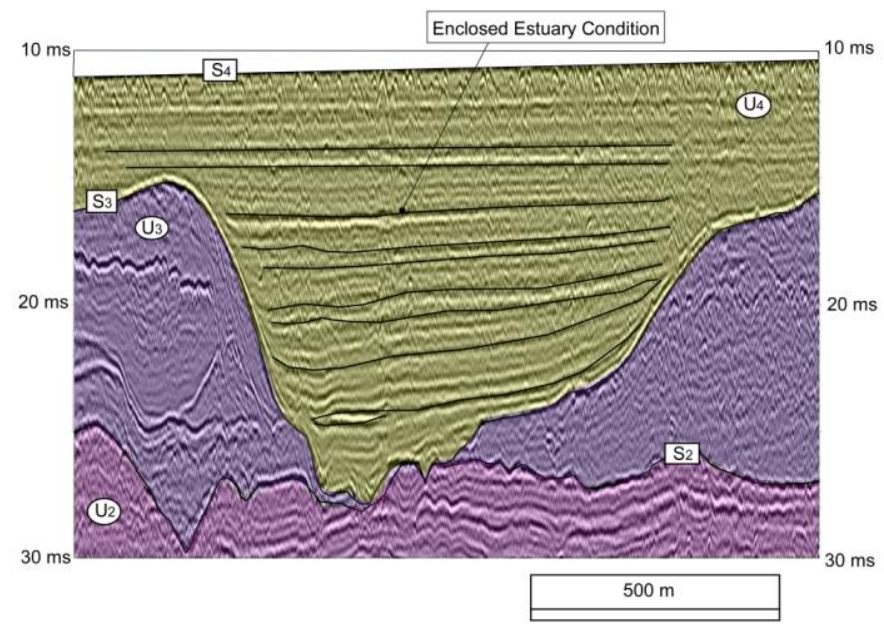

Figure 10 - Paleochannel identified in the study area characterized by continuous plane-parallel reflectors, showing a deposition in low energy environment

\section{Conclusions}

At the moment, this study allowed to identify four seismic units showing the evolution of the Sepetiba, showing that the region was not sediment starved. So far the results led us to a complex paleo-river system excavated in the last glacial maxima, when the continental shelf was exposed. The rise of the sea level gradually drowned this ancient river system changing the fluvial system to a high energy fluvial estuarine system. The continuous sea level rise in consonance if the growth of the current barrier island, provoke a change in the configuration of the bay, that gradually drowned the paleo-river system, passing into a low energy estuary until the total closure of the barrier island, Restinga da Marambaia

\section{Acknowledgments}

- Geomargem, Universidade do Estado do Rio de Janeiro

\section{References}

BORGES, H.V. 1998. 145p. Holocene Geological Evolution of Sepetiba Bay and Marambaia Barrier Island, Brazil. Dissertation (PhD in Coastal Oceanography), Marine Sciences Research Center, State University of New York. New York. 1998.

FRIEDERICHS, Y.L. O sistema fluvio-estuarino da baía de Sepetiba preservado na estratigrafia rasa da plataforma interna adjacente (RJ). 2012. $181 \mathrm{p}$. Dissertação (Mestrado em Oceanografia). Faculdade de Oceanografia, Universidade do Estado do Rio de Janeiro, Rio de Janeiro. 2012. 
FRIEDERICHS, Y.L. et al. Arquitetura sísmica do sistema fluvio-estuarino da baía de Sepetiba preservado na estratigrafia rasa da plataforma adjacente, Rio de Janeiro, Brasil. Brazilian Journal of Geology, 43(1), p.124138. 2013.

MATTOSO, Y. M. Evolução do Sistema de Paleocanais da Baía de Sepetiba. Monografia (Bacharelado em oceanografia). Faculdade de Oceanografia, Universidade do Estado do Rio de Janeiro.2014

PONÇANO, W.L.; FÚLFARO, V.J; GIMENEZ, A.F. Sobre a origem da Baía de Sepetiba e da Restinga da Marambaia, RJ. In: SIMPÓSIO REGIONAL DE GEOLOGIA, 2, 1979, Rio Claro. Anais... Rio Claro, 1979 p. 291-304. 